\title{
Religion, theology and the social sciences in a society in transition
}

\author{
Etienne de Villiers \\ Department of Systematic Theology and Christian Ethics \\ University of Pretoria
}

\begin{abstract}
The societal changes introduced with the advent of the new political dispensation in South Africa in 1994 brought with them serious consequences for the different religions and for the academic disciplines devoted to the study of religion. This includes disciplines such as theology and religious studies, as well as those social sciences with an academic interest in religion as influential societal factor. The second part of the article presents a brief survey of the impact of these societal changes on religion, particularly the Christian religion, and the academic disciplines of theology, religious studies and the social sciences. An outline of the position and role of religion and the academic disciplines of theology, religious studies and the social sciences in the apartheid society from which South Africa is evolving, is used as point of departure in the first part of the article. The third part of the article ventures beyond mere description of the position and role of religion and the different academic disciplines involved with the study of religion. It aims to make out a case that in the New South Africa religion and academic disciplines exclusively devoted to the study of religion, such as theology, need the social sciences.
\end{abstract}

\section{INTRODUCTION}

In Wahrheit und Methode Hans-Georg Gadamer rightly asserts that even during times of drastic change far more of the old is retained than one would ever imagine. ${ }^{1}$ This is also true of the present South African society, a society in transition. It does not, however, take away that those involved in these changes are far more aware of the disruptive effects of these changes on their lives than the underlying stability. What they experience is often a complete breakdown of a familiar world and the displacement of this world by a strange new world. This is also the case in South Africa. Many people in our society -

\footnotetext{
${ }^{1}$ Viz Wahrheit und Methode,266: "Selbst wo das Leben sich sturmgleich verändert, wie in revolutionären Zeiten, bewahrt sich im vermeintlichen Wandel aller Dinge weit mehr vom Alten, als irgendeiner weiss, und schliesst sich mit dem neuen zu neuer Geltung zusammen."
} 
from different cultures and different walks of life - have the experience since 1990 of being caught up in a rollercoaster ride from which they cannot escape and that leaves them bewildered and overwhelmed.

The transition that we are experiencing in South Africa is at its core the transition from a society predominantly structured by powers of restoration to one increasingly structured by the powers of modernisation. It is a transition that has a severe impact on social institutions, including religion. The South African society indeed provides theology, religious studies and the social sciences with excellent opportunities to undertake firsthand research on the impact of drastically accelerated modernisation on religion and religious denominations. It also provides the opportunity to study the impact of rapid societal changes on theology, religious studies and the social sciences themselves. For none of these disciplines have escaped the drastic and even disruptive influence of transition in the New South Africa.

In this article, more particularly the second part of it, I am presenting a brief survey of the impact of societal changes in the present South Africa on religion, particularly the Christian religion, and the academic disciplines of theology, religious studies and the social sciences. For the sake of comparison I am taking my point of departure in the first part of the article in a sketch of the position and role of religion and the academic disciplines of theology, religious studies and the social sciences in the apartheid society from which South Africa is evolving. In the third part of the article I venture to go beyond the mere description of the position and role of religion and the academic disciplines involved in the study of it. I am trying to make out a case that religion and academic disciplines exclusively devoted to its study, like theology, need the social sciences in the New South Africa.

\section{RELIGION, THEOLOGY AND THE SOCIAL SCIENCE IN THE APARTHEID SOCIETY}

\subsection{Religion in the apartheid society}

The South African society is and has always been a strongly religious society. In a 1995 World Values Study, 81\% of South African respondents reported that they considered themselves to be religious, with $98 \%$ of those surveyed stating they believed in God, and $70.7 \%$ rating God's importance to them as 10 on a scale of 1-10 (where 10 equals "very important") (Venter 2002:174). The complete dominance of the Christian religion is conspicuous - despite the fact that the South African population includes people belonging to quite a variety of religions, amongst others Islam, Hinduism, Judaism and indigenous religions. According to the 1996 census $74.1 \%$ of the population can be 
classified as Christian (down from a high of $77 \%$ in 1980). Interestingly enough, these statistics reflect also the percentage of black Christians in the present South Africa rather accurately. The black Christian population grew from $26.2 \%$ in 1911 to $77.2 \%$ in 1991, before it declined to 75\% in 1996 (Hendriks \& Erasmus 2002:27).

Undeniably the political, economic and cultural hegemony of initially the Western colonisers from The Netherlands and Great Britain and later the white population of an independent South Africa contributed to the predominance of the Christian religion. The predominance of the Christian religion was, however, not gained without resistance from the indigenous black religions. As the statistics reveal the Christian religion only gained its predominance amongst blacks in the course of the $20^{\text {th }}$ century.

Traditionally oriented blacks were mostly drawn into the African Independent Churches (AICs), at present the largest single religious grouping in South Africa. AIC affiliation in South Africa currently stands at over 10,6 million people, based on the 1996 census. This translates into $26.3 \%$ of all South African Christians, and almost one out of every three black Africans (Venter 2002:182). In contrast to the mainline and Pentecostal churches, the four to six thousand AICs have not disentangled themselves from the social practices connected with the ancestral cult, but in different degrees reflect the hybridisation of the Christian and traditional African religion (Venter 2002:184). In a unique way, one may say, they also represent the resistance of African culture and religion to the domination of Western culture and religion.

In the apartheid society the AICs were marginalised and hardly had any public influence. The socially predominant Christian denominations were undoubtedly the Afrikaans churches, guided by their own blend of the Reformed confession. By the time the National Party took over political power in 1948 a unique symbiosis between the Afrikaans speaking Reformed churches and the Afrikaner people had already taken place. After his visit to South Africa in 1952 the former secretary of the WCC, Visser't Hooft remarked in his report: "There are few nations in the world in which one can find such a strong alliance and symbiosis of Church and people as one finds among the Afrikaner" (Visser't Hooft 1952).

In a recent publication $\mathrm{J}$ Durand convincingly argued that the close relationship between the Afrikaans churches and the Afrikaner people had been facilitated by the version of the Reformed religion that came with the Dutch settlers to South Africa in the $17^{\text {th }}$ century (Durand 2002:32-39). During the $17^{\text {th }}$ century the Reformed Church in The Netherlands was deeply influenced by a movement of Reformed pietism with its roots in English 
Puritanism. This Reformed pietism did not upset the existing tradition of a "people's church", but rather strengthened it by emphasising the Puritan ideal that life in its entirety should be brought to obedience to the law of God. In addition the doctrines of election by God and the covenant between God and his people played a central role. In the different setting of South Africa these ideas evolved over a period of time into the convictions that the Dutch Reformed Church and the two smaller Afrikaans Reformed churches were exclusively for the Afrikaner people and that the Afrikaner people is an elected people with whom God had made a covenant. For the Afrikaner people this covenant comprised the pledge by God to keep them as a people, as well as the undertaking on their side to Christianise South Africa. Against this background it is not surprising that the Afrikaans churches during the apartheid era took it for granted that their interpretation of the implications of God's law was binding for society as a whole.

Some of the consequences of this close relationship between the Afrikaans churches and the Afrikaner people in the apartheid era, can be briefly summarised:

- $\quad$ The Afrikaans churches strongly influenced government policy.

- $\quad$ Ministers of religion of the Afrikaans churches were granted status and influence in the public sphere that was out of proportion.

- It was taken for granted by both the Afrikaans churches and the government that South Africa is and should be a Christian country. This assumption found expression in, for example, the 1983 constitution one of two constitutions introduced during the reign of the National Party. It was stated in this constitution that one of the national objectives was "to maintain Christian values and civilised norms and to recognise and protect freedom of worship" (Lubbe 2002:64). In trying to prevent the introduction of legislation that would allow commerce on Sunday the general synod of the Dutch Reformed Church as late as 1990 "expresse(d) its conviction, based on the principles of the Holy Scripture, that in a Christian country, no economic or other principles, but only the principles of the Holy Scripture may determine legislation on commerce on Sunday" (Proceedings of the General Synod of the DRC1990:489).

- The geographical and political isolation of South Africa, the influence of the Afrikaans churches in the public sphere, the predominance of Christian values in most spheres of society, but also the almost instinctive dislike of most Afrikaners of anything "liberal", had as result that the South African society was protected far more effectively and far 
longer against the intrusive influence of the processes of modernisation and secularisation than European societies (viz Durand 2002:40-50). Already during the eighties, however, one could experience that the resistance against the forces of modernisation was dwindling and that the South African society was changing.

\subsection{Theology and the social sciences in apartheid society}

The predominance of Christian religion in the apartheid society was reflected in the privileged position of theology. Except for a few liberal academics at the so-called "English" universities no-one questioned the existence of Faculties of Theology at state universities, even though they were for the most part racially segregated and some had a rather narrow denominational basis. Student numbers were no problem, because it was a popular career choice to become a minister of religion. The number of students was bolstered by the introduction of biblical studies as a university subject for non-theological students. During the heydays of biblical studies it was a course taken by thousands of students, especially students who wanted to become teachers. In comparison to theology the academic discipline of religious studies played a backstage role. Departments of Religious Studies that favoured a neutral approach to the study of the different religions were operating at only a few of the liberal "English" universities. In the theological faculties at the so-called "Afrikaans" universities religions other than the Christian were at most studied in the context of the theological discipline of missiology.

Theologians played a leadership role in universities and in society. They served in government commissions and in the executive committees of national cultural organisations. The public media sought after their opinion on a spectrum of public issues. Interesting enough, it was not only theologians at the Afrikaans universities who played centre stage in the South African society. Especially after many of the leaders of the liberation movement in South Africa were sent to prison or became political fugitives in other countries, church leaders and theologians took over the task of criticising the government and championing the cause of the liberation movement. The government's hesitancy to prosecute church leaders and theologians reflects something of the exceptionally high status they had in the previous political dispensation.

The price theology and theologians paid for this privileged position in apartheid society was to be almost inevitably drawn into the fierce ideological struggle that was waged. It is a well-known fact that theologians of the Afrikaans churches played a pivotal role in the theological justification of apartheid. The late Professor E Groenewald, a New Testament scholar at the 
Faculty of Theology of the University of Pretoria, drew up the first official report of the Dutch Reformed Church that attempted to provide a biblical justification for apartheid in1947. Professor J Heyns, in life a professor of systematic theology at the same Faculty of Theology, was chairperson of a committee of chaplains in the defence force that in the eighties advised the government not to recognise so-called "selective" conscientious objectors who regarded the war against the liberation movement as unjust. Dr. A. Nolan was an example of a theologian who attempted to theologically legitimate the liberation struggle of specifically the ANC, the United Democratic Front and COSATU by depicting them in his book God in South Africa as channels for God's power of liberation in South Africa (Nolan 1988:262-265).

Even those theologians who tried to avoid legitimating the cause of one of the two sides in the ideological struggle, could - to a large extent - not avoid to be drawn into academic debates on apartheid and the struggle between the government and the liberation movements. Topics relating to apartheid and the struggle dominated theological discussions. One of the results was that very few theologians were involved at the time in international theological discussions on topics of a more fundamental and general nature (De Villiers \& Smit 1994:238).

The position of the social sciences in the apartheid society was not that much different from the position of theology. Although perhaps not as privileged, their position was nonetheless a favourable one. At most of the universities Faculties of the Humanities were the largest faculties and had no problems in attracting adequate numbers of students. Quite a number of social scientists played prominent roles in society. Like theologians many of them also could not avoid to be drawn into the ideological struggle.

Sociologists like G Cronjé and N Rhoodie, both from the University of Pretoria, helped to provide a theoretical basis for apartheid, while an economist like F R Tomlinson was chairperson of a government appointed committee that laid the groundwork for the homeland policy of the Nationalist government. Social scientists also counted amongst the most vocal critics of apartheid and repressive measures taken by the government. F van Zyl Slabbert was a sociologist who did not only voice academic criticism against the government, but also became the leader of the opposition in the parliament. A Erwin, presently serving in the cabinet of the South African government, was one of a number of Marxist lecturers in economy at South African universities who actively supported the liberation struggle.

The effect of the ideological struggle between the government and the liberation movement on the social sciences could also be felt in shifts that occurred in their study of religion. In a survey of the recent history of the 
academic discipline of sociology of religion in South Africa Venter points out that teaching and research in this discipline peaked in the seventies and then declined in the course of the eighties. One of the reasons he identifies is the rise to prominence since the late seventies of Marxist theory in South African sociology, especially in the sociology departments at the Universities of the Witwatersrand and of Cape Town. The Marxist view of religion as a peripheral phenomenon was bound to affect the place of religion within the discipline. He also notices a certain narrowing of the interest of the social sciences in religion. From the 1970s onwards religion was considered primarily in terms of whether it contributed to or inhibited political change (Venter 2002:172-173).

\section{RELIGION, THEOLOGY AND THE SOCIAL SCIENCES IN THE NEW SOUTH AFRICA}

\subsection{Religion in the New South Africa}

In this article the term "society in transition" refers to the rapidly changing South African society since the introduction of a new political dispensation in 1994, the so-called New South Africa. It would, however, have made perfect sense to interpret this term as referring rather to the transition from the apartheid society to the New South Africa. The role religion, theology and the social sciences played in the transitory period preceding the introduction of the new political dispensation would then have been the topic under discussion.

In passing I would like to make only one remark relating to the transition from the apartheid society to the New South Africa. As in the former DDR in the period preceding the unification of Germany, churches, church leaders and theologians played quite a significant role in South Africa in helping to bring about a peaceful transition. At the end of the eighties and the beginning of the nineties a number of South African churches openly supported peaceful negotiations between the liberation organisations and the Nationalist government. Church leaders and theologians, including my predecessor professor Heyns, worked very hard behind the scenes to persuade rightwing political groups not to resolve to violence in order to prevent the transfer of political power. In their own way they contributed to what is now often referred to as the "miracle" of the peaceful transition to the New South Africa.

As in the case of Germany after unification, South African churches, church leaders and theologians found that appreciation for their role in the peaceful transition did not translate in the New South Africa into privileged public roles. It is true that quite a number of church leaders were rewarded 
with political posts for their contribution in the liberation struggle and as politicians have continued to play influential public roles. The experience of the churches and those who remained church leaders and theologians was rather one of a severe loss of public influence. In the case of the Afrikaans churches and church leaders and theologians involved with them, this is hardly surprising. With the transfer of political power to an ANC controlled government they, probably forever, lost their privileged position as close partners of the government with a direct say in policy matters. The loss of public influence of black and English churches and church leaders, who actively supported the liberation struggle, was partly and ironically the result of the success of the liberation struggle. In the New South Africa it was no longer necessary for churches and church leaders to fill the political vacuum that was left with the banning of liberation organisations and the imprisonment of their leaders and to play a vicarious political leadership role.

There is, however, another important factor that added to the churches' loss of public influence. The new liberal constitution, for the first time in South African history, clearly insists on the separation of religion and state. This makes it difficult - if not impossible - for the government to implement the distinctive views of a particular religious group, leave alone the distinctive views of a particular religious denomination within that religious group. It is clear that the separation of religion and state in the New South Africa has - up till now - caused considerable confusion and uncertainty among churches that were used to direct involvement in public matters. It is especially the case with the Afrikaans churches. Their direct involvement in public matters in the previous political dispensation was based on their strong belief in the theocratic ideal for politics that forms part and parcel of their Reformed confessional tradition (viz the Confessio Belgica, Section 36). According to this ideal the state is seen as an obedient servant of God that has to make a religious choice in favour of the Christian faith, promote Christian values in its policies and has the responsibility to protect the true Christian religion. In the present political dispensation the state is seen as a purely human institution that has to obey the will of the majority, may not favour any particular religion, has to promote a set of common human values, expressed in the bill of rights and has to ensure religious freedom to all religious institutions (De Villiers 2001:51-52).

Since 1994 the Afrikaans churches have had to grapple not only with what their basic stance over against the new liberal democracy should be, but also with how they should react to the liberalisation of, amongst others, abortion, censorship and gambling legislation, as well as to the invitation of the government to civil society to become constructively involved in the 
government's Reconstruction and Development Programme. They have been torn between an almost instinctive tendency to criticise any development in society that are not in accordance with traditional Christian values and the recognised need to accommodate the new human rights culture and to play a constructive role in helping to solve the multitude of societal problems in our new democracy. The challenges they have been - and still are - faced with in this regard are, first of all, to find a satisfactory normative basis for constructive involvement in society and, secondly, to overcome the lack of motivation of many of their members to become constructively involved in society. Many members of the Afrikaans churches did not take positively to developments in the South African society since 1994. After the initial euphoria about the "miracle" of a peaceful transfer of political power, they had to face the consequences of the loss of political power. Primarily Afrikaner people experienced the brunt of accusations in the TRC hearings, retrenchment and unemployment as a result of the implementation of affirmative action in the civil service and the threat of expropriation as a result of the government's land reform programme. In addition to that an increasing number of them became the victims of a wave of crime, including violent crime that has swept South Africa since 1994. Negative feelings about the New South Africa led to the emigration of a considerable number of white people to countries like Australia, New Zealand, Canada and Great Britain. It also led to what Moltmann called the "inward emigration" of a considerably greater number of white people (Moltmann 1974:37-41). Many of them have completely dissociated themselves from what happens in the public sphere and have withdrawn to their own private sphere of purely personal relationships, interests and religious experiences (De Villiers 1999:23-24).

The introduction of a liberal democracy in South Africa is part of a more comprehensive process of modernisation that has accelerated considerably since 1994. The breakdown of political and economic isolation, the demise of the public influence of the Afrikaans churches and the conservative Christian values they promulgated, the separation of religion and state in the new constitution, and, especially, the dominance of political liberalism with its emphasis on individual freedom, have led to a situation where there is apparently very little that can hold back modernisation and concomitant processes like globalisation, secularisation and individuation in the South African society. The effects of these processes on religious institutions can already be noticed. I mention a few of the effects on mainline Afrikaans and English churches with which I am familiar: 


\section{Religion, theology and the social sciences in a society in transition}

- $\quad$ There is a growing variety of views and spiritualities within church denominations. This is partly due to the fact that the views of church and theological authorities on moral and doctrinal issues are not uncritically accepted anymore and members tend to make up their own mind. It has, however, also to do with the fact that church members and their pastors are exposed far more than before to alternative views and spiritualities in the South African society and from overseas.

- Many church members experience a crisis with regard to their Christian identity. Not all church members celebrate the greater variety of views and spiritualities they experience in their churches. As a result of the fact that their sense of Christian identity has been closely linked with the traditional confessional beliefs and spirituality of a particular church denomination they experience the increasing variety of beliefs and spiritualities as a threat to their own Christian identity.

- $\quad$ Orthodox dogmatic and moral beliefs are increasingly questioned and debated. The widely publicised recent debate on the views of the socalled "New Reformers" on the virgin birth and resurrection of Christ is one example. The campaign that is waged in certain churches for the moral condoning of homosexual relationships is another example.

- $\quad$ There is a decline in the percentage of the population that are Christian. In the case of the population of South Africa as a whole this decline is rather small: $2.9 \%$ from 1980 to 1996 . In the case of whites the decline is more dramatic. Until 1980 over $90 \%$ of whites associated with the Christian religion. Then the decline started, from $91.4 \%$ in 1980 , to $77.9 \%$ in 1991 , to $77.5 \%$ in 1996 . This means, as one commentator puts it, that "the typical Western pattern of a declining Christianity, which struck Europe after the Second World War, and the USA after the sixties, became visible statistically in South Africa as from 1980" (Jurgens \& Erasmus 2002:29). In the words of another commentator: "There does seem to be an indication that a secular, post-modern, "post-Christendom" is developing" (Kritzinger 2002:5).

To emphasise only the negative impact that societal forces in the New South Africa have on mainly the mainline Afrikaans and English churches, would be to forget that a number of religious denominations experience the new political dispensation as far more beneficial than the previous one. This is true of previously marginalised Christian denominations such as the AICs, but is even more true of non-Christian religions such as Judaism, Islam and Hinduism. They receive much more public recognition than before (for example at the inauguration ceremonies of pres Nelson Mandela and pres 
Thabo Mbeki) and have their fair share of religious programmes in the mass media and of religious observances in public schools.

Some are even of the opinion that there is a revival in the New South Africa of the traditional animistic religion of the blacks. Primal understandings of reality in which people live in an interconnected relationship with all other beings in the universe through vital participation were destroyed in modernity in other parts of the world, but seem to survive and even to flourish in the South Africa. This, at least, is the view of Ashforth, an anthropologist, who lived for some years in Soweto before and after April 1994. He documented his experience in a book entitled Maduna - a man bewitched (2000) in which he moots the idea that there is more "witchcraft" activity after the demise of apartheid than there was before. He argues that the myth that apartheid was the cause of every evil in the lives of black South Africans has had, with its demise, to be replaced by more traditional myths of the presence of evil spirits. The ancestors have been re-summoned, as it were, to give new explanations of the situation (Balcomb 2003:19).

\subsection{Theology and the social sciences in the New South Africa}

Theology as an academic discipline has undoubtedly lost its privileged position in the New South Africa. In fact, one may go so far as to say that its position at state universities is, to a certain extent, under threat. The present precarious situation of theology can be contributed to at least four factors:

- $\quad$ Due to the fact that the career choice of minister of religion was such a popular one in the late seventies and early eighties, far more theological students completed their studies since the mid-eighties than the churches could absorb. It resulted in a cumulative surplus of hundreds of theological graduates who had to wait years before they could be appointed by churches, or eventually had to resort to alternative career possibilities. As could be expected this in turn led to a severe drop in the number of theological students since the beginning of the nineties. As a result of the difficult financial situation many congregations find themselves in, there is little chance that church demand for theological graduates will increase in the foreseeable future.

- $\quad$ The drop in student numbers coincided with the introduction of business management principles in the running of South African universities since the beginning of the nineties and the setting of economic and technological development as training and research priorities for tertiary education by the new government since 1994 . 
What has counted since then has not been so much the traditional status of an academic faculty or discipline or the meaning it adds to human existence, but rather its functional value in contributing directly to development and progress in society. On that count theology has not fared too well. Even more important has been the criterion of being a financial asset to the university by attracting many students and maintaining a favourable student-lecturer ratio. On that count theology has fared even worse. The result has been that theological faculties have been put under pressure by university authorities to draw more students and to rationalise their personnel. Two universities decided to give their faculties of theology not even the chance to redeem themselves, and closed them down.

- The faculties of theology at the former Afrikaans universities found themselves at the advent of the new political dispensation in the uncomfortable position of respectively providing only theological training for one or two Afrikaans churches and having very few black students and almost no black faculty members. They have been put under pressure by university authorities to diversify in the composition of not only their student bodies, but also of their staff. Most of them have in the meantime succeeded to attract more black and female students. What proved to be a particularly difficult feat has been to appoint more black and female lecturers, while at the same time trying to meet the demand to rationalise personnel. As a result most of these faculties of theology still do not have a staff composition that would satisfy university authorities or the government.

- What poses even a greater threat to theology as academic discipline and to theological faculties is the strong campaign that is presently waged by proponents of a more inclusive and more neutral approach to the study of religion in educational institutions. One of the most influential proponents of what can be called the religious studies approach is prof J S Krüger, head of the Department of Religious Studies at the University of South Africa. In public debates up till now he and other proponents of this approach have concentrated on religious education in public schools, because the government is in the process of finalising its policy with regard to it. Krüger proposes an integrated-pluralistic model in which the pupil will be educated to know and understand all the major religions in South Africa. This model would - in his view - not only promote mutual understanding and tolerance, but would harness the enormous power of various religions to motivate and inspire (Krüger 2002:222-224). 
It is clear that this approach also has implications for theological education at state universities. It would probably only be a matter of time before a campaign will be launched to replace the present particularistic model of theological education - as Krüger would call it - with the integrative-pluralistic model of religious studies. Krüger has already expressed himself strongly against the exclusively Christian faculties of theology at South Africa universities. He regards such faculties as discriminatory and monopolistic remnants of the previous political dispensation in which Christianity was the favoured religion. In the present democratic dispensation in which no discrimination on religious ground are tolerated, exclusively Christian faculties of theology need to be replaced by departments or faculties of religious studies where Christianity is studied in the context of the religions of the world in plural.

(Krüger 2002:229-230)

The New South Africa has, however, not only brought bad news for theology. One very positive development is that theological faculties have been forced to relinquish their exclusive relationship with only one or two church denominations and to become more inclusive and ecumenical. The cooperation with a greater variety of church denominations and the broadening of the gender, cultural and confessional basis of their student bodies and staff have proven to be stimulating and enriching. As a result of their more inclusive approach faculties of theology have gained the trust of many of the new leaders in society. They are therefore also better geared to play a constructive role in helping to solve societal problems. The academic isolation of the apartheid era has finally been broken through and many fruitful academic partnerships with overseas colleagues could be initiated. An increasing number of South African theologians attend conferences overseas, take part in international discussions and contribute to international journals and publications.

In many respects the position of the social sciences in the New South Africa is not much different from that of theology. The most important difference is that the university status of the social sciences as academic disciplines is not fundamentally questioned, as it is the case with theology. The shift in government priorities for tertiary education and the strong tendency among students to opt for more "useful" and "applied" university courses that would enhance their career possibilities have, however, also in the case of the social sciences led to a severe decline in student numbers in the nineties. At most of the South African universities Faculties of Economic and Management Sciences have now become the biggest faculties with the most students and faculty members. The decline in student numbers has also 
in the case of the social sciences led to pressure to rationalise personnel and to find ways to attract more students. One way in which social science departments have tried to make their courses more marketable has been to design applied courses that are tailor made for students who prepare themselves for a business or professional career. This often has as consequence that less attention is given in tuition and research to topics that have in the past been regarded as central to a particular social science, but are now not fashionable or marketable anymore. In his research on the position of the discipline of sociology of religion at South African universities Venter found that one of the main reasons for the termination of courses in sociology on religion during the last two decades has been the pressure exerted on Departments of Sociology with dwindling staff to produce marketable courses that would prepare student for the employment market (Venter 2002:172-173).

\title{
4. WHY RELIGION AND THEOLOGY NEED THE SOCIAL SCIENCES IN THE NEW SOUTH AFRICA
}

In this last part of my article I would like to substantiate the claim that, especially in this period of rapid societal change, religion and theology in South Africa need the social sciences. One could, of course, also try to make out a case that the reverse is just as true, namely that the social sciences in South Africa need religion and theology. Someone who tries to make out such a case is the South African born sociologist Venter. In Venter's (2002:173) discussion of the demise of the discipline of sociology of religion in South Africa, he comes to the conclusion

\begin{abstract}
that South African sociologists' lack of interest in studying religion ultimately harms the discipline of sociology more than other disciplines. Sociology suffers most because an important social factor is ignored in sociological analysis. In the process the analytical reach of sociology is severely curtailed and the theoretical contributions that could result from the study of religion, as the founding figures of sociology demonstrated, are lost.
\end{abstract}

As theologian I would rather leave the task of demonstrating why the social sciences in South Africa need religion and theology to social scientists themselves.

In my opinion there are at least three reasons why religion, more particularly organised religion, and theology need the support of social scientific research in the New South Africa: 
- To know what is really going on in our society: to get a reliable picture of the factors that are shaping society and of the impact that it has on society, and more particularly on organised religion and theology as academic discipline. There is no way that organised religion and theology can go forward in a responsible and effective way if they do not have a clear picture in this regard. And the only way in which they can get such a reliable picture is by relying on social scientific research.

What they need, first of all, is more insight into the process of modernisation and concomitant processes like secularisation, individuation and globalisation. As I have already pointed out, these are the predominant societal forces that are now changing and shaping our society, including organised religion and theology, in a drastic way. In this regard we can, no doubt, learn much from groundbreaking research that has been done by European and American social scientists. I am, for example, of the opinion that work done by social scientists like Tomlinson and Giddens on cultural globalisation can shed light on what we are experiencing in South Africa today. Tomlinson uses the term "deterritorialisation" to describe the effect of globalisation on local culture, including local religion. This term points to the fact that the complex connectivity of the world in which we are living weakens the connection of culture to a particular locality. Although most of us find ourselves most of the time in particular localities, these localities are gradually and subtly losing the power to determine our lives as a result of the fact that we are increasingly influenced by cultural factors that have their origin in other parts of the world (Tomlinson 1999:106-149). In my opinion Tomlinson's thesis on deterritorialisation accounts for much of the alienation from traditional religious beliefs and practices that church members are experiencing in South Africa. Giddens has convincingly demonstrated that traditions that regulate everyday life, and especially traditions regulating intimate relationships, are now for the first time seriously coming under fire as a result of globalisation (Giddens 2000:69-84). According to him fundamentalism - including religious fundamentalism - is a contemporary phenomenon that can only be adequately understood as a form of resistance against the onslaught of globalisation on tradition (Giddens 2000:66-68). These views of Giddens shed light on the loosening of the grip of religious tradition on everyday life, especially on intimate relationships, as well as the upsurge of religious fundamentalism amongst certain Christian and Islamic groups in South Africa. 
Insights that are gained from the social sciences with regard to modernisation and its concomitant processes need to be assimilated and applied to the church and its mission in the present world in a convincing and responsible way. In this regard I am of the opinion that Wolfgang Huber, bishop of the EKD in Berlin-Brandenburg and chairperson of the Council of the EKD, provides to us a model in his book Kirche in der Zeitenwende: Gesellschaftlicher Wandel und Erneuerung der Kirche (1999) that is worth emulating in South Africa. Relying strongly on insights from the social sciences Huber in this book honestly and incisively takes account of the negative effects of processes like secularisation and individuation on the church as institution and of opportunities still left to the church to exert a public influence in contemporary democratic societies.

- $\quad$ With that we have already touched on a second reason why religion and theology need the social sciences: to help to ascertain whether the conditions still exist for organised religion in the New South Africa to exert a public influence. As Reformed theologian I am especially intrigued with the question: "What opportunities do the churches in a democratic South Africa still have to play a transforming role in society now that the traditional theocratic approach of striving to attain a Christian society based on distinctive Christian values has become obsolete?" This is, of course, a question with which we as South African theologians have to grapple ourselves. We can, however, learn much from the work of social scientists. Beyer, for example, has - in my opinion - argued convincingly that the predominance of globalisation as the contemporary outcome of the process of modernisation does not necessarily mean that the public role of religion has been played out. The reason for this is that global instrumental systems such as the capitalist economic, sovereign state, scientific, health and educational systems are totalising, in the sense that they are applicable to anything in their environment, but not allencompassing, because there is much that they exclude (Beyer 2001:266). Among these are the meaning and thematising of the social whole, the "private sphere" or "life world" and many problematic effects of their operation. This is where religion, as the one mode of communication that is in principle both totalising and encompassing, can and does play an important role. It can and does serve as a kind of system specialisation that deals with what, from the perspective of the dominant functional systems, are residual matters. Religion's role in this regard is typically "anti-systemic" in the sense that religious 
adherents, leaders and professionals tend to see their communication as essential because it addresses the problems that the dominant systems either leave out or create without solving. "Anti-systemic" may mean against the dominant structures and values of emerging global society, as is clearly the case with some contemporary forms of fundamentalist religion. The "anti-systemic" role of religion can, however, also be "pro-systemic" in the sense that liberal moral values like equality and freedom, which are - in Beyer's opinion - inherent to the social systems of modernity, are taken as point of departure in criticising the negative effects of these systems, as is the case in liberal Christianity (e g the WCC) (Beyer 2001:273).

As South African theologians we, of course, have to take into account that our society is an African one. Still only a minority of the population are predominantly Westerly orientated, with predominantly individualist values and attitudes. The majority of the African population still adhere to values and display attitudes that are, to a lesser or greater extent, communal in nature. It may be that we, in the end, have to conclude that the strong privatisation of religion and even the sharp differentiation of the social systems that are typical of Western societies, does not apply to the same extent to our new democracy. The work of some social scientists points in this direction. Although Casanova accepts the differentiation of social systems in Western societies as valid, he argues that the privatisation of religion is a historical option, but not a necessary one. It was the authoritarian role of religion in Europe that facilitated the privatisation of religion. The exclusive limitation of religion to the private domain of life did not necessarily flow from the factors that gave rise to secularisation. The public role of religion may therefore - in his view - be compatible with democratic institutions and religion could still play an important role in civil society by humanising the rational systems of modernity (Casanova 1994:39).

In discussing Casanova's views Tayob, a lecturer in religious studies at the University of Cape Town, argues that not only the privatisation of religion, but also the differentiation that are typical of Europe, have no counterpart in postcolonial societies in Africa. The reason is that Casanova's prime factors of differentiation: religious reformation, state formation, capitalism and scientific developments, are either absent or distorted in these societies. The lack of differentiation does not, however, translate in religion playing a transforming role in postcolonial African states. The opposite is rather 
the case. Unlike Europe, where debates have raged within religious traditions about the transformation of society, critical debates are almost non-existent. Religions in post-independent societies seem happy to demand a fair share of the state's support and resources in exchange for loyalty (Tayob 2002:12).

Already from this brief discussion regarding the existence of the necessary conditions for religion to exert a salutary transforming influence on society in South Africa, it has become clear that much research needs still to be done by both social scientists and theologians before a definite answer can be given.

- $\quad$ A third reason for saying that religion and theology need the social sciences is: Social science has to challenge them when the views they promulgate and the attitudes they instil in religious people have negative consequences for society. Organised religion and theology have to take responsibility for the consequences (often unforeseen consequences) of their views and practices. They do not, however, have the tools of scientific empirical research and, especially, not the necessary unbiased attitude over against their own views and practices to reliably gauge these consequences. This is where the social sciences can fulfil an indispensable function with regard to religion and theology.

I mention only two issues that need to be further researched by the social sciences, both pertaining to religious views and attitudes with regard to AIDS. The first is the view of certain Christian churches on the so-called ABC strategy in preventing the spread of AIDS. As a result of the success of this strategy in curtailing HIV infection in Uganda, where it was implemented for the first time, it is also propagated in South Africa. The rationale behind the strategy is that if people could be convinced to Abstain from sexual intercourse as far as possible, to $B e$ faithful to their partners once they become involved in a sexual relationship and to Condomise when they have sexual intercourse, especially outside faithful relationships, the spread of HIVIAIDS infection would be severely curtailed. Some churches in South Africa, for example the Roman Catholic Church, reject this strategy because it would imply that sexual intercourse outside marriage is morally acceptable. To these churches the only morally acceptable option for single persons is abstinence and for married persons faithfulness to their spouses. In his book God in AIDS? A theological inquiry the South African theologian Ronald Nicolson criticises this view of the churches. By insisting in an absolutist way that 
even in the context of the combat against HIVIAIDS in Africa, only the Christian ideal of sexual abstinence outside marriage can be accepted as morally responsible behaviour, these churches' contribution to this combat is, in his opinion, counter-productive. In the real life situation of disrupted family life and poverty in Africa many people find it impossible to refrain from sexual relationships outside marriage. Migrant labourers in cities, for example, are away from their wives in rural areas for the greatest part of the year and very often have intimate relationships with other women. To confront them with the message that only abstinence outside marriage is morally responsible sexual behaviour would be to no avail. They need to be convinced that even when they cannot refrain from sexual relationships outside marriage they have to maintain an optimal sexual morality of remaining faithful to their partners, as far as possible, and of using condoms when they have casual sex (Nicolson 1996:100-152; see also De Villiers 2003:34). It is clear that Nicolson's criticism is not only based on theological and ethical presuppositions, but also on the factual presupposition that the conservative view of some churches is an impediment to an effective strategy against the spread of HIV infection. It is only the social sciences that can help to find a decisive answer on whether the rejection of the $A B C$ strategy by some churches do have such negative consequences.

The second issue has to do with the reasons for the high percentage of people who are HIV infected in Southern Africa, and, more particularly, in South Africa. Do traditional African religion and culture have anything to do with it? What has become clear during the last few years is that there is a certain unwillingness among certain black people, including some black leaders, in South Africa to relate AIDS and the deaths caused by it to sexual behaviour and to accept that responsible sexual behaviour forms an indispensable part of the combat against HIVIAIDS. I personally experienced the angry outburst of a well-educated black male at an AIDS forum against the appeal for a new, more responsible, sexual morality in our country. There may be other important reasons for this unwillingness, but the question still remains whether it can, in one way or another, be related to the continuing influence of traditional African religion and culture.

It is a well researched fact that in traditional African religion and culture no sharp distinction between the self and the outside world is made. To quote K C Anyanwu: "The unity of the self and the world, mind and matter, is something magical because it defies any rational understanding. We can only say that the self and the world 
interpenetrate each other in such a way that we do not know where the self begins and ends for the world to begin" (Ruch \& Anyanwu 1981: 91). One of the consequences of this view is that misfortunes experienced by the self are often causally related to hostile spiritual forces coming from outside the self. Even guilt is often externalised and personalised by the traditional African. When she fails to achieve a certain goal or falls ill the self is not necessarily held responsible, but other persons who are believed to have poisoned her or have mobilised evil forces against her by bearing malice against her, or by bewitching her. She does therefore not need so much forgiveness for sins that she committed and conversion to morally responsible behaviour, than protection against external evil forces that threaten her life. Protection from such evil forces is sought through rituals performed and conduct and potions prescribed by traditional healers or diviners (Taylor 1963:176-177).

On the face of it the persisting influence of such traditional African beliefs, be it in hybridised form, could at least partly account for the unwillingness of certain black people to relate the AIDS that they have contracted to their own sexual behaviour, or to seek prevention of HIV infection by means of morally responsible sexual behaviour. It could also account for the high incidence of the use of traditional medicine in an attempt to cure AIDS and for the widespread belief that sleeping with a virgin could cure someone from AIDS. Again, it is only social science research that can provide clarity on the role, if any, traditional African religion and culture are playing in the spread of HIV infection in South Africa.

\section{CONCLUSION}

In this article I have sketched a picture of the position of religion, theology and the social sciences in the apartheid era. I have also described the impact that rapid societal changes in the New South Africa have had on religion, theology and the social sciences by highlighting those effects that would - in my opinion - interest both theologians and social scientists. In the last part of the paper I have presented a case that religion and theology in the New South Africa need the social sciences. Hopefully it has not only become clear that theology and the social sciences share a rather similar position in the New South Africa, but also share a common interest in religion and have much to offer to each other. 


\section{Works consulted}

Ashforth A 2000. Maduna: A man bewitched. Cape Town: David Philip.

Balcomb, T 2003. Which story do we follow? "Culture wars" and the issue of public morality on Canaan's side of the Jordan. Scriptura 82, 15-22.

Beyer, P 2001. The global environment as a religious issue: A sociological analysis, in D Herbert (ed), Religion and social transformations, 261-212. Aldershot, UK: Ashgate.

Casanova, J 1994. Public religions in the modern world. Chicago, IL: University of Chicago Press.

De Villiers, D E 1999. Die NG Kerk en die oorgang na 'n nuwe Suid-Afrika. Skrif en Kerk 20(1), 15-38.

De Villiers, D E 2001. The influence of the DRC on public policy during the late 1980's and 1990's. Scriptura 76, 51-61.

De Villiers, D E 2003. A Christian ethics of responsibility: Does it provide an adequate theoretical framework for dealing with issues of public morality?. Scriptura 82, 23-38.

De Villiers, D E \& Smit, D J 1994. Hoe Christene in Suid-Afrika by mekaar verby praat: Oor vier morele spreekwyses in die Suid-Afrikaanse kerklike konteks. Skrif en Kerk 15(2), 228-247.

Durand, J 2002. Ontluisterde wêreld: Die Afrikaner en sy kerk in 'n veranderende wêreld. Wellington: Lux Verbi.

Gadamer, H-G 1972. Wahrheit und Methode: Grundzüge einer philosophischen Hermeneutik. Tübingen: J C B Mohr.

Giddens, A 2000. Runaway world: How globalization is shaping our lives. New York, NY: Routledge

Hendriks, J \& Erasmus, J 2002. A general statistical picture of religion in South Africa, in D Kritzinger (ed), No quick fixes: Challenges to mission in a changing South Africa, 13-30. Pretoria: IMER.

Huber, W 1999. Kirche in der Zeitenwende: Gesellschaftlicher Wandel und Erneuerung der Kirche. Gütersloh: Gütersloher Verlagshaus

Kritzinger, D (ed), No quick fixes: Challenges to mission in a changing South Africa. Pretoria: IMER

Krüger, J S 2002. From one to many. The challenge of religious pluralism: The teaching of Christianity in state schools and universities in South Africa, in Spoor, 207-234. Pretoria: Aurora Press.

Lubbe, G 2002. Religio-political changes in South Africa, in D Kritzinger (ed), No quick fixes: Challenges to mission in a changing South Africa, 61-69. Pretoria: IMER.

Moltmann, J 1974. Man: Christian anthropology in the conflicts of the present. London: SPCK.

Nicolson, R 1996. God in AIDS? A theological inquiry. London: SCM.

Nolan, A 1988. God in South Africa: The challenge of the gospel. Cape Town: David Philip.

Proceedings of the General Synod of the DRC 1990. 
Religion, theology and the social sciences in a society in transition

Ruch, E A \& Anyanwu, K C 1981. African philosophy: An introduction to the main philosophical trends in contemporary Africa. Rome: Catholic Book Agency.

Taylor, J V 1963. The primal vision. London: SCM.

Tayob A 2002. Religion, culture and identity in a democratic society. Journal for the Study of Religion 15(2), 5-13.

Tomlinson, J 1999. Globalization and culture. Chicago, IL: University Press.

Venter, D 2002. What is sociology that religionists should be mindful of it? The relevance of the sociology of religion for studying change in South Africa. Journal for the Study of Religion 15(2), 167-189.

Visser't Hooft, W A 1952. Visit to the South African churches. Geneva: WCC. 